\title{
PENGARUH MODEL PEMBELAJARAN BERBASIS MASALAH TERHADAP HASIL BELAJAR DAN KETERAMPILAN BERPIKIR KRITIS SISWA DI KELAS X SMA NEGERI 16 MEDAN
}

\author{
Ratelit Tarigan, Ami Salmiah \\ Jurusan Fisika, Fakultas Matematika dan Ilmu Pengetahuan Alam, Universitas Negeri \\ Medan \\ email: tarigan_unimed@yahoo.com
}

\begin{abstract}
ABSTRAK
Telah dilakukan penelitian yang bertujuan untuk mengetahui pengaruh model pembelajaran berbasis masalah terhadap hasil belajar dan keterampilan berpikir kritis siswa di SMA Negeri 16 Medan. Jenis penelitian ini adalah quasi eksperimen. Populasi dalam penelitian adalah seluruh siswa kelas X yang terdiri dari 4 kelas. Pengambilan sampel dilakukan dengan cara cluster random sampling dengan mengambil 2 kelas, yaitu kelas X MIA 4 sebagai kelas eksperimen dan kelas X MIA 3 sebagai kelas kontrol. Hasil penelitian menunjukkan 100\% siswa pada kelas eksperimen mencapai nilai KKM dengan rata-rata hasil belajar kelas eksperimen 82,93 dan di kelas kontrol sebesar 90\% siswa mencapai nilai KKM dengan nilai rata-rata 75,75 . Hasil uji t diperoleh bahwa terdapat perbedaan hasil belajar akibat pengaruh model pembelaran pada kedua kelas dan nilai rata-rata tes keterampilan berpikir kritis kelas eksperimen 81,70 dan kelas kontrol 75,75. Hasil uji t diperoleh bahwa terdapat perbedaan keterampilan berpikir kritis siswa akibat pengaruh model pembelajaran yang dilakukan pada kedua kelas. Hasil penilaian ini menunjukkan bahwa penerapan model pembelajaran berbasis masalah mampu meningkatkan hasil belajar siswa dan mengarahkan siswa untuk lebih berpikir kritis sehingga mudah memahami materi pembelajaran.
\end{abstract}

Kata kunci : model pembelajaran berbasis masalah, hasil belajar dan keterampilan berpikir kritis siswa

\footnotetext{
ABSTRACT

The aim of this research is to know the effect of problem based-learning model on students' achievement and students' critical thinking skill in SMAN 16 Medan. Kind of this research is experimental research. The population is all the students in grade $\mathrm{X}$ which were consisted of 4 classes. The sample that the researchers used is cluster random sampling by taking 2 classes, that is X MIA 4 as an experimental class and X MIA 3 as a control class. The result from this research was shown that $100 \%$ students from experimental class could achieve KKM score with the average 82,93 and the control class could achieve KKM score with the average 75,75. From t test we got there is a difference of students' achievement it is caused by the effect of learning model from both classes with the average of critical thinking skill test in experimental class could achieve 81,70 and control class 75,75. From t test we got word there is a difference of students' critical thinking skill that is caused by learning model that has already done in 2 classes. The result of this research has shown that the application of problem
} 
based-learning model could increase students' achievement and also could let the students think critically and it will make them easy to understand the material.

Keywords : problem based-learning model, students'achievement and students' critical thinking skill

\section{PENDAHULUAN}

Upaya

mencerdaskan

kehidupan bangsa dan meningkatkan kualitas sumber daya manusia seutuhnya adalah misi pendidikan yang menjadi tanggung awab profesional setiap guru. Dalam mengajar bukan lagi usaha untuk menyampaikan ilmu pengetahuan, melainkan usaha untuk menciptaka sistem lingkungan yang membelajarkan peserta didik agar tujuan pengajaran dapat tercapai secara optimal. Kenyataan di lapangan, cara guru mengajar masih banyak yang terlalu menekankan pada penguasaan sejumlah informasi/konsep belaka. Hal ini menyebabkan banyak siswa tidak menyukai pelajaran terutama pelajaran fisika dan merasa bahwa pelajaran fisika merupakan pelajaran yang sangat sulit karena selalu berkaitan dengan rumus.

Pernyataan di atas juga diperkuat dari hasil observasi yang dilakukan di SMA N 16 Medan yang menunjukkan bahwa hasil belajar siswa yang dicapai pada umumnya kurang mencapai nilai KKM. Berdasarkan Daftar Kumpulan Nilai (DKN) siswa kelas $\mathrm{X}$ tahun ajaran 2014 - 2015 pada aspek penguasaan dan penerapan konsep diketahui nilai rata-rata yang diperoleh adalah 73,5. Nilai yang dicapai siswa dikategorikan cukup, nilai tersebut tidak murni diperoleh siswa dari hasil belajarnya sendiri melainkan sudah ada tambahan dari guru, diantaranya adalah penilaian guru terhadap tugas pribadi, kehadiran siswa, disiplin siswa, dan juga keaktifan siswa pada saat proses balajar mengajar berlangsung. Sejalan dengan hal ini peneliti juga melakukan penelitian awal dengan menyebarkan angket kepada 42 orang siswa kelas X SMA Negeri 16 Medan, didapat $50 \%$ siswa berpendapat bahwa pelajaran fisika merupakan pelajaran yang sulit dan $28 \%$ siswa berpendapat biasa saja, berdasarkan hasil angket ini maka diketahui Kebanyakan siswa menganggap fisika merupakan pelajaran yang terkesan sulit, kurang meyenangkan.

Hasil wawancara dengan guru kelas X SMA Negeri 16 Medan menunjukkan adanya permasalahan yang dihadapi oleh guru selama KBM. Masalah ini kemungkinan disebabkan karena penggunaan model pengajaran yang kurang tepat, sehingga menyebabkan siswa tidak menyukai mata pelajaran fisika yang disampaikan oleh guru. Permasalahan ini terlihat dari kurangnya siswa dalam memunculkan pertanyaan, masalah yang penting dan merumuskannya kurang jelas dan tepat. Siswa belum biasa mengumpulkan dan menilai informasi yang relevan serta menggunakan ideide abstrak untuk menafsirkannya secara efektif.

Kenyataannya secara umum guru fisika cenderung menggunakan metode ceramah. Guru fisika 
cenderung menggunakan metode tersebut disebabkan keterbatasan waktu, mengejar materi dan sarana prasarana yang kurang memadai. Pembelajaran yang kurang melibatkan siswa secara aktif menyebabkan kurang seimbangnya kemampuan kognitif, afektif dan psikomotorik siswa. Sebagian besar dari siswa juga tidak mampu memghubungkan antara apa yang dipelajari dengan bagaimana pengetahuan tersebut akan dimanfaatkan atau dipergunakan. Tentu saja hal tersebut cenderung membuat siswa terbiasa menggunakan sebagian kecil saja dari potensi atau kemampuan pikirnya. Untuk memecahkan masalah pembelajaran tersebut perlu dilakukan upaya antara lain berupa perbaikan strategi pembelajaran yaitu model pembelajaran yang diharapkan mempermudah siswa dalam berpikir kritis dan ketrampilan memecahkan masalah sehingga tercapai hasil yang lebih maksimal

Siswa yang memiliki keterampilan berpikir kritis akan mampu mengolah apa yang dibacanya, dibahas ataupun dilihat sehingga dapat menemukan sesuatu yang memiliki makna bagi dirinya. Keterampilan ini berkaitan dengan keterampilan mengidentifikasi, menganalisis dan memecahkan masalah secara kreatif dan berpikir logis sehingga menghasilkan pertimbangan dan keputusan yang tepat. Keterampilan berpikir kritis bukan merupakan suatu keterampilan yang dapat berkembang dengan sendirinya seiring dengan perkembangan fisik manusia. Keterampilan ini harus dilatih melalui pemberian stimulus yang menuntut seseorang untuk berpikir kritis. Menurut Fisher (2009) berpikir kritis sebagai proses aktif, sebagian karena ia melibatkan dalam tanya jawab dan sebagian karena peran yang dimainkan metakognitis, keterampilan ini dapat meningkatkan pemahaman dalam banyak konteks. Sekolah sebagai suatu institusi penyelenggara pendidikan memiliki tanggung jawab untuk membantu siswanya mengembangkan keterampilan berpikir kritis. keterampilan berfikir kritis membutuhkan proses, intruksi yang terus menerus dan praktik dalam mengembangkannya secara maksimal. Tan (2004) mengungkapkan bahwa Kemampuan berpikir kritis tidak akan terjadi jika tujuan siswa hanya mendapatkan nilai untuk memasuki jenjang yang lebih tinggi. Ada empat komponen dasar dari definisi berpikir kritis yaitu: keterampilan dasar, basis pengetahuan, kemauan untuk bertanya dan refleksi diri.

Menurut Ibrahim dan Nur (2000), Pembelajaran berbasis masalah tidak dirancang untuk membantu guru memberikan informasi sebanyak banyaknya kepada siswa, akan tetapi dikembangkan untuk membantu siswa mengembangkan keterampilan berpikir, pemecahan masalah, dan keterampilan intelektual, belajar berbagai peran orang dewasa melalui pelibatan mereka dalam pengalaman nyata dan menjadi pebelajar yang mandiri. Hasil penelitian terdahulu menunjukkan bahwa pembelajaran berbasis masalah mampu meningkatkan hasil belajar dan keterampilan berpikir kritis siswa. 
Adapun tujuan penelitian ini yaitu 1) Untuk mengetahui bagaimana hasil belajar siswa setelah menepakan model pembelajaran berbasis masalah, 2) Untuk mengetahui bagaimana keterampilan berpikir kritis siswa setelah menepakan model pembelajaran berbasis masalah, 3) untuk mengetahui apakah ada perbedaan hasil belajar siswa setelah menerapkan model pembelajaran berbasis masalah dengan pembelajaran konvensional, 4) untuk mengetahui apakah ada perbedaan keterampilan berpikir kritis siswa setelah menerapkan model pembelajaran berbasis masalah dengan pembelajaran konvensional

\section{METODE PENELITIAN}

Penelitian ini dilakukan di SMA Negeri 16 Medan Jl. Kapten Rahmad Buddin Kelurahan Terjun, Medan Marelan selama 5 bulan (maret sampai juli). Populasi dalam penelitian adalah seluruh siswa kelas $X$ SMA Negeri 16 Medan T.P 2014/2015 yang terdiri atas 4 kelas. Pengambilan sampel dilakukan dengan teknik pengambilan sampel acak berkelompok (cluster random sampling), diambil 2 kelas yaitu kelas $\mathrm{X}$ MIA 4 sebagai kelas eksperimen diajarkan model pembelajaran berbasis masalah dan kelas X MIA 3 sebagai kelas kontrol diajarkan dengan pembelajaran konvensional. Jenis penelitian quasi experiment. quasi experiment

Desain penelitian ini adalah Two Group pre-test-post-test design atau desain yang menggunakan pretes dan postes dengan kelompok yang diacak. Desain penelitian ini dapat dilihat pada tabel 1 .
Tabel 1. Two Group pre-test-post-test design (Arikunto, 2006)

\begin{tabular}{|l|c|c|c|}
\hline \multicolumn{1}{|c|}{ Kelas } & Pretes & $\begin{array}{c}\text { Perlak- } \\
\text { uan }\end{array}$ & Postes \\
\hline eksperimen & $\mathrm{T}_{1}$ & $\mathrm{P}$ & $\mathrm{T}_{2}$ \\
\hline Control & $\mathrm{T}_{1}$ & $\mathrm{Q}$ & $\mathrm{T}_{2}$ \\
\hline
\end{tabular}

Keterangan :

$$
\begin{aligned}
& \mathrm{P}=\text { Pembelajaran dengan } \\
& \mathrm{T}_{2}=\text { Postes diberikan setelah }
\end{aligned}
$$

Pengumpulan data dalam penelitian ini dilakukan dengan metode observasi dan metode tes. Instrumen yang dipersiapkan yaitu perangkat pembelajaran, lembar pengamatan, tes hasil belajar dan tes keterampilan berpikir kritis berbentuk esaai dengan 10 soal. Sebelum data diolah menggunakan uji $t$ untuk mengetahui pengaruh model pembelajaran berbasis masalah terlebih dahulu dilakukan penilaian pretes, uji normalitas (uji Lilliefors), uji homogenitas (uji F) dan uji kesamaan rata-rata pretes (uji t).

\section{HASIL DAN PEMBAHASAN}

Mengenai identifikasi hasil pretes dan postes, analisis dan pembahasan, uji hipotesis, serta 
keterlaksanaan model pembelajaran berbasis masalah

Berdasarkan tes hasil belajar yang telah dilakukan di SMA Negeri 16 Medan diperoleh data pretes untuk kelas eksperimen dengan jumlah siswa 44 orang memperoleh nilai rata-rata sebesar 26,56 dengan nilai tertinggi 35 dan nilai terendah adalah 17. Untuk kelas kontrol dengan jumlah siswa 41 orang memperoleh nilai rata-rata pretes sebesar 27,09 dengan nilai tertinggi 36 dan nilai terendah 16. Data yang diperoleh ditunjukkan pada tabel 2 .

Tabel 2. Data Nilai Pretes Kelas Eksperimen dan Kelas Kontrol

\begin{tabular}{|c|c|c|c|c|c|}
\hline \multicolumn{3}{|c|}{$\begin{array}{l}\text { Data nilai pretes } \\
\text { kelas eksperimen }\end{array}$} & \multicolumn{3}{|c|}{$\begin{array}{c}\text { Data nilai pretes } \\
\text { kelas kontrol }\end{array}$} \\
\hline Nilai & $\mathrm{F}_{\mathrm{i}}$ & $\begin{array}{c}\text { Rata- } \\
\text { rata }\end{array}$ & Nilai & $\mathrm{F}_{1}$ & $\begin{array}{c}\text { Rata- } \\
\text { rata }\end{array}$ \\
\hline $15-18$ & 6 & \multirow{6}{*}{26,56} & $15-18$ & 4 & \multirow{6}{*}{27,09} \\
\hline $19-22$ & 7 & & $19-22$ & 6 & \\
\hline $23-26$ & 9 & & $23-26$ & 8 & \\
\hline $27-30$ & 10 & & $27-30$ & 10 & \\
\hline $31-34$ & 7 & & $31-34$ & 8 & \\
\hline $35-38$ & 5 & & $35-38$ & 5 & \\
\hline Jumlah & 44 & & Jumlah & 41 & \\
\hline
\end{tabular}

Data postes untuk kelas eksperimen dengan jumlah siswa 44 orang memperoleh nilai rata-rata postes sebesar 82,93 dengan nilai tertinggi adalah 91 dan nilai terendah adalah 74. Untuk kelas kontrol dengan jumlah siswa 42 orang memperoleh nilai rata-rata postes sebesar 75,75 dengan nilai tertinggi adalah 84 dan nilai terendah adalah 68. Data yang diperoleh ditunjukkan pada tabel 4.2 dibawah ini.
Tabel 3. Data Nilai Postes Kelas

Eksperimen dan Kelas Kontrol

\begin{tabular}{|c|c|c|c|c|c|}
\hline \multicolumn{3}{|c|}{$\begin{array}{l}\text { Data nilai postes } \\
\text { kelas eksperimen }\end{array}$} & \multicolumn{3}{|c|}{$\begin{array}{l}\text { Data nilai postes } \\
\text { kelas kontrol }\end{array}$} \\
\hline Nilai & $\mathrm{F}_{\mathrm{i}}$ & $\begin{array}{c}\text { Rata- } \\
\text { rata }\end{array}$ & $\mathrm{F}_{\mathrm{i}}$ & Nilai & $\begin{array}{c}\text { Rata- } \\
\text { rata }\end{array}$ \\
\hline $74-76$ & 5 & \multirow{6}{*}{82,93} & $68-70$ & 6 & \multirow{6}{*}{75,75} \\
\hline $77-79$ & 7 & & $71-73$ & 8 & \\
\hline $80-82$ & 8 & & $74-76$ & 9 & \\
\hline $83-85$ & 9 & & $77-79$ & 8 & \\
\hline 86-88 & 8 & & $80-82$ & 6 & \\
\hline $89-91$ & 7 & & $83-85$ & 4 & \\
\hline Jumlah & 37 & & Jumlah & 34 & \\
\hline
\end{tabular}

Data tes keterampilan berpikir kritis untuk kelas eksperimen dengan jumlah siswa 44 orang memperoleh nilai rata-rata postes sebesar 81,70 dengan nilai tertinggi adalah 93,3 dan nilai terendah adalah 72,2. Untuk kelas kontrol dengan jumlah siswa 42 orang memperoleh nilai rata-rata postes sebesar 77,90 dengan nilai tertinggi adalah 87,5 dan nilai terendah adalah 70. Data yang diperoleh ditunjukkan pada tabel 4 .

Tabel 4. Data Nilai keterampilan berpikir kritis Eksperimen dan Kelas Kontrol

\begin{tabular}{|c|c|c|c|c|c|}
\hline \multicolumn{3}{|c|}{$\begin{array}{c}\text { Data Nilai } \\
\text { Keterampilan } \\
\text { Berpikir Kritis Kelas } \\
\text { Eksperimen }\end{array}$} & \multicolumn{3}{|c|}{$\begin{array}{c}\text { Data Nilai } \\
\text { Keterampilan } \\
\text { Berpikir Kritis Kelas } \\
\text { Kontrol }\end{array}$} \\
\hline Nilai & $\mathrm{F}_{\mathrm{i}}$ & $\begin{array}{l}\text { Rata } \\
\text {-rata }\end{array}$ & Nilai & $\mathrm{F}_{\mathrm{i}}$ & $\begin{array}{l}\text { Rata } \\
\text {-rata }\end{array}$ \\
\hline $71,6-74,5$ & 6 & \multirow{6}{*}{81,7} & $69,5-72,5$ & 6 & \multirow{6}{*}{77,9} \\
\hline $74,6-78,5$ & 8 & & $72,6-75,5$ & 8 & \\
\hline $78,6-82,5$ & 10 & & $75,6-78,5$ & 9 & \\
\hline $82,6-86,5$ & 8 & & $78,6-81,5$ & 8 & \\
\hline $86,6-90,5$ & 7 & & $81,6-84,5$ & 6 & \\
\hline $90,6-94,5$ & 5 & & $84,6-87,5$ & 4 & \\
\hline Jumlah & 44 & & Jumlah & 41 & \\
\hline
\end{tabular}




\section{Pembahasan}

Hasil

penelitian ini menunjukkan adanya peningkatan hasil belajar siswa kelas eksperimen dari nilai rata-rata pretes sebesar 26,56 dan tidak ada seorang pun siswa yang mencapai KKM sebesar 70 menjadi sebesar 82,93 pada nilai rata-rata postes dimana seluruh siswa mencapai nilai KKM. Begitu juga terhadap kelas kontrol dengan menggunakan pembelajaran konvensional terhadap hasil belajar siswa juga menunjukkan adanya peningkatan hasil belajar. Hal ini ditunjukkan dengan meningkatnya hasil belajar siswa dari nilai rata-rata pretes kelas kontrol sebesar 27,09 dan tidak ada seorang pun siswa yang mencapai KKM sebesar 70 menjadi sebesar 75,75 pada nilai rata-rata postes dengan jumlah siswa yang mencapai KKM sebanyak 37 orang dari 41 orang siswa.

Selain itu, dari hasil penelitian diperoleh juga nilai keterampilan berpikir kritis siswa di kelas eksperimen dengan rata-rata 81,70 sedangkan dikelas kontrol diperoleh nilai rata-rata yang lebih rendah yaitu 77,90

maka hasil penelitian ini
menunjukkan adanya perbedaan model pembelajaran berbasis masalah dengan pembelajaran konvensional terhadap hasil belajar siswa pada materi pokok suhu dan kalor di kelas $\mathrm{X}$ semester II SMA negeri 16 Medan T.P. 2014/2015. Perbedaan hasil belajar yang diperoleh dari kelas eksperimen dan kelas kontrol tersebut karena pada kelas eksperimen yang diberikan pengajaran bebasis masalah memunculkan kreativitas dan antusias siswa dalam belajar. Hal ini dapat dilihat dari proses pembelajaran yang dilakukan, yaitu pada tahap orientasi masalah dalam pembelajaran siswa menjawab pertanyaan dari guru, selain itu hal yang paling memberikan dampak pada hasil belajar ini yaitu ketika dalam proses menyelesaikan masalah yang diselesaikan secara berkelompok. Kegiatan ini dilakukan siswa dengan perintah dan bimbingan dari guru. Setelah mendapat bimbingan tersebut siswa dituntut untuk dapat menyelesaikan permasalahan yang dimunculkan dalam diskusi. Dan hal ini membuat siswa lebih aktif dalam berdiskusi. Dalam proses pembelajaran siswa pada kelas eksperimen siswa dapat menjawab permasalahan yang diberikan bukan hanya melalui teori namun juga mebuktikan teori dengan hasil yang sebenarnya yang dibuktikan melalui percobaan dan ditunjukkan dengan alat peraga. Penggunakaan strategi dan media pembelajran menjadikan siswa lebih aktif dan termotivasi dalam belajar begitu juga dengan penggunaak alat peraga memudahkan siswa dalam memahami materi pelajaran. Sedangkan pada kelas kontrol dikarenakan proses belajar mengajar menggunakan pembelajaran konvemsional maka metode eksperimen dalam pembelajaran ini tidak dilakukan, dan guru hanya menjelaskan dengan media pembelajaran.

Model pembelajaran berbasis masalah dalam penerapannya menuntut siswa untuk berpikir kritis dan mampu menyelesaikan permasalahan yang diajukan. Sesuai pengembangannya menurut Eggen dan Kauchak (2012) pembelajaran berbasis masalah menggunakan 
masalah sebagai fokus untuk mengembangkan keterampilan pemecahan masalah, materi (konten) dan pengendalian diri. Hal ini memberikan kesempatan kepada siswa bereksplorasi mengumpulkan dan menganalisis data untuk memecahkan masalah, sehingga siswa mampu berpikir kritis, analisis, sistematis dan logis dalam menemukan alternatif pemecahan masalah. Siswa dalam hal ini aktif dan antusias untuk bekerja sama dengan teman satu kelompok dalam menyelesaikan masalah yang telah diberikan oleh peneliti. Siswa juga tertarik dan aktif dalam berdiskusi dan mengeluarkan perndapat yang berbeda saat diadakan diskusi antar kelompok. Hal ini sangatlah berbeda dengan pembelajaran konvensional yang hanya memberikan dan menjelaskan materi tanpa menuntut siswa untuk mengumpulkan dan mengeksplorasi data untuk dipecahkan dalam suatu permasalahan. Keterampilan berpikir kritis yang dianalisis menunjukkan bahwa ada perbedaan keterampilan berpikir kritis siswa akibat pengaruh model pembelajaran berbasis masalah dan konvensional, besar peningkatan keterampilan berpikir kritis adalah sebesar $4,87 \%$

Selain hasil belajar dalam penelitian ini juga dilakukan pengamatan sikap dan keterampilan siswa.

Hasil penelitian ini juga sesuai dengan hasil penelitian yang telah dilakukan oleh beberapa peneliti sebelumnya. Berdasarkan hasil penelitian Azizah (2014) menunjukkan bahwa terdapat peningkatan hasil belajar siswa setelah menerapkan model pembelajaran berbasis masalah. kenaikan hasil belajar siswa juga diikuti dengan kenaikan kemampuan berpikir kritis siswa setelah diterapkan model pembelajaran berbasis masalah. Selain itu hasil temuan penelitian Setyorini (2011) juga menunjukkan hal yang saama dimana terdapat peningkatan hasil belajar yang diiringi peningkatan keterampilan bepikir kritis siswa setelah mengikuti pembelajarn berbasis masalah.

Adapun kendala-kendala dalam penelitian yaitu : 1) keterbatasan peneliti dalam mengembangkan indikator berpikir kritis pada instrumen penelitian sehingga hasil yang diperoleh belum maksimal. 2) penyusuan instrumen tes hasil belajar belum sepenunya sesuai dengan model pembelajaran berbasis masalah, 3) keterbatasan peneliti dalam pengembangan LKS dan pemilihan masalah yang dan masih perlunya upaya pengembangan LKS dan permasalahan yang sesuai dengan model, 4) keterbatasan peneliti dalan mengalokasikan waktu pada saat siswa melakukan percobaan dan mengajukan hasil diskusi. 5) kurangnya pengalaman peneliti dalam mengelola kelas sehingga kondisi siswa yang ribut menyebabkan penelitian menjadi kurang efisien. 6) sarana dan prasarana yang kurang lengkap, 7) pemberian waktu untuk menyelesaikan soal kurang diprediksi sehingga waktu yang diberikan untuk menyelesaikan soal terlalu singkat

\section{KESIMPULAN DAN SARAN}

Berdasarkan hasil analisis yang dilakukan dalam penelitian ini diperoleh kesimpulan 
Bahwa Hasil belajar fisika siswa di kelas ekperimen setelah menerapkan model pembelajaran berbasis masalah mevapai ketuntasan individu sebesar $100 \%$ dan ketuntasan kelas sebesar 54\%. Keterampilan berpikir kritis siswa di kelas eksperimen mencapai ketuntasan individu sebesar $100 \%$ dan ketuntasan kelas sebesar 52\%. Hasil uji statistika data hasil belajar siswa menunjukkan bahwa terdapat perbedaan hasil belajar siswa akibat pengaruh model pembelajaran berbasis masalah. Dan hasil uji statistika data keterampilan berpikir kritis menunjukkan bahwa terdapat perbedaan keterampilan berpikir kritis siswa akibat pengaruh model pembelajaran berbasis masalah di kelas X SMA Negeri 16 Medan.

Berdasarkan hasil penelitian ini, maka peneliti mengajukan beberapa saran bagi pihak yang ingin menerapkan model ini selanjutnya, yaitu :

1. Bagi siswa sebaknyanya lebih melatih keterampilan dalam melakukan tugas kelompok dan kegiatan percobaan.

2. Bagi sekolah sebaiknya melengkapi saran dan prasarana untuk mendukung proses belajar mengajar disekolah.

3. Bagi peneliti selanjutnya sebaiknya menguasai penerapan model pembelajaran berbasis masalah pada pelaksaan.

4. Bagi peneliti selanjutnya sebaiknya lebih mengoptimalkan pengembangan instrumen berpikir kritis dan hasil belajar sesuai dengan model PBL.

5. Bagi peneliti selanjutnya sebaiknya memilih permasalahan yang akan disajikan dalam lembar kerja siswa yang lebih mudah difahami, dan menggunakan soal-soal instrumen yang lebih baik.

\section{DAFTAR PUSTAKA}

Arikunto, S., (2006), Prosedur Penelitian Suatu Pendekatan Praktik, Penerbit Bumi Aksara, Jakarta.

Azizah, N., Fatmaryanti, D.S., dan Ngazizah, N. (2014), Penerapan Model Pembelajaran Konstruktivisme Berbasis Problem Based Learning (PBL) Untuk Meningkatkan Keterampilan Berfikir Kritis Pada Siswa SMA Negeri 1 Kutowinangun Kelas X Tahun Pelajaran 2013/2014, Journal Pendidikan Fisika Universitas Muhammadiyah Purworejo, Vol: 5 No: 2

Eggen, P. dan Don Kauchak, (2012) Strategi dan Model

Pembelajaran, Indeks, Jakarta

Fisher, A. (2009), Berpikir Kritis, Erlangga, Jakarta

Ibrahim, M. dan Nur, M., (2000), Pengajaran Berdasarkan Masalah, Unesa University Press, Surabaya

Tan, O., (2004), Enhancing Thinking Through Problem Base

Learning Approaches, Cengage Learning, Singapura

Setyorini, U., Sukiswo, S.E., Suball, B., (2011), Penerapan Model Problem Based Learning untuk Meningkatkan Keterampilan Berpikir Kritis Siswa SMP, Jurnal Pendidikan Fisika Indonesia 7, ISSN: 1693-1246 